\title{
A Research on the Effect of Altruistic Behaviour on Employee Satisfaction in Larsen \& Toubro, Chennai
}

\author{
Mincy Mohan, V Sasirekha
}

\begin{abstract}
Organizational citizenship behaviour is a very important antecedent to ensuring organizational success. This study has focused on one of the major antecedent of $\mathrm{OCB}$, which is altruism. The study has been conducted among the employees at L\&T Construction, Chennai. The total population is 500 and a sample of 100 was taken based on convenience sampling. Exploratory research design was used. Data collection was done by means of questionnaire. The questionnaire focussed on measuring the altruistic behaviour of the employees and thereby figuring out the extent of satisfaction these employees enjoy, if there is a relationship between both. The result of the study indicated that altruism had a positive impact on satisfaction which in turn always has a positive effect on any job a person does. The findings of the study are important to impart motivation and further fuel altruistic behaviour.
\end{abstract}

\section{Keywords: Employee satisfaction, Altruism}

\section{INTRODUCTION}

OCB refers to that behaviour exhibited by an employee as a result of his own interest. This behaviour is no way a result of force from the management or colleagues. These behaviours are basically termed as extra role behaviour. OCB does not account for during performance appraisal.

The greatest advantage when an employee exhibits OCB is that it not only enhances his own performance due to boost in confidence but also enhances the performances of others due to the morale support they receive. The ultimate impact of all these is the satisfaction which the employees derive. One fine example of an employee exhibiting OCB is an employee assisting a new joinee at his own interest, defending the reputation of his organization in public, always sticking to the policies, rules etc.,

OCB also influences group performance. The reason is that OCB contributes to improvement in inter personal relationships which address all issues pertaining to being in a group and the challenges attached there with.

OCB has many dimensions to be studied and they are more than 30. This study focuses on Altruism.

\section{Altruism}

Altruism means willingly being selfless and extending helping hand to co-workers despite all the inconveniences or difficulty a person faces. Altruism or helping behaviour is exhibited by means of actions like extending helping hand to a junior who needs support in work, helping out an employee

Mincy Mohan, Research and Development Centre, Bharathiyar University, Coimbatore-641 046, Tamil Nadu, India. University, Coimbatore-641 046, Tamil Nadu, India.
Revised Version Manuscript Received on 10, September 2019.

Dr. V Sasirekha, Research and Development Centre, Bharathiyar

meet his targets or deadlines when he falls back due to reasons like sickness etc., And all these are done despite knowing that spending time in helping out can result in loss of one's own time and might have to end up extending beyond office hours. Despite knowing that such actions do not earn him or her any sorts of monetary or non-monetary benefits; employees go ahead with their actions which are termed as altruistic behaviour. It is one of the major antecedents of OCB. The essence of altruism is love, self-sacrifice, empathy etc.,

\section{Employee Satisfaction}

By employee satisfaction, one does not simply mean if the employee is satisfied with his salary. It is broader term which encompasses the satisfaction which an employee enjoys with regard to his job satisfaction, job description, team relationship, superior subordinate relationship, monetary and non-monetary benefits enjoyed etc.,

\section{Figure 1: Conceptual Framework}

\section{Independent Variable \\ Dependant Variable \\ Altruism -------- $\mathbf{H}_{01}$ Employee Satisfaction}

The study tested the following null hypotheses:

Hol: Altruism has no significant effect on employee performance

\section{METHODOLOGY \& RESULTS}

Exploratory research design was used in this study. A sample of 100 was selected from a total population of 500 . The study used questionnaire in data collection.

Table1: Sample Size

\begin{tabular}{|l|l|l|l|}
\hline Index & $\begin{array}{l}\text { Branch } \\
\text { Name }\end{array}$ & Population & Sample \\
\hline 1 & $\begin{array}{l}\text { Manapakk } \\
\text { am }\end{array}$ & $\mathbf{5 0 0}$ & $\mathbf{1 0 0}$ \\
\hline
\end{tabular}

\section{DATA ANALYSIS AND PRESENTATION}

\subsection{Results and Dimensions}

Out of 100 questionnaires distributed to the respondents, all 100 questionnaires were returned, which gives a response rate of $100 \%$

\section{Correlation Results}

The study uses correlation analysis to figure out the relationship between the two variables of the study which are 
altruism, and employee satisfaction. The results are presented in Table below.

Findings revealed that altruism was positively and significantly associated with employee satisfaction $(\mathrm{r}=$ $0.811, \rho<0.01$ ) indicating $81.1 \%$ positive relationship with employee satisfaction.

Table 2: Correlation Results

\begin{tabular}{|c|c|c|c|}
\hline & $\begin{array}{c}\text { Employee } \\
\text { Satisfactio } \\
\text { n }\end{array}$ & Altruism & $\begin{array}{c}\text { Co u r t e s } \\
\text { y }\end{array}$ \\
\hline $\begin{array}{c}\text { Employee } \\
\text { Satisfaction }\end{array}$ & 1 & & \\
\hline Altruism & $8 \quad 1 \quad 1$ & 1 & \\
\hline \multicolumn{2}{|c|}{ Correlation is significant at the 0.01 level (2-tailed) } \\
\hline
\end{tabular}

\section{(Source Data 2019)}

\section{Percentage Analysis Results}

- Majority of the respondents i.e. $49 \%$ of the respondents have been with L\&T for over 5 years which is a good sign of citizenship behaviour. 40\%, 5\%, 4\%, $2 \%$ have been with L\&T for less than 5 years, 10-15 years, 15-20 years and 20-25 years respectively.

- A very good proportion of respondents have given positive sign by agreeing that they help out co-workers by adjusting work schedule, show genuine courtesy towards co-workers. This is a clear exhibition of Citizenship behaviour.

- $62 \%$ of the Employees' say that they willingly giving time to help co-workers when they have work related problems, $63 \%$ of the respondents agree that they willingly take time off from busy schedule to orient or train new Employees'. This indicates that more than $60 \%$ of the respondents exhibit altruistic dimension of OCB.

\section{CONCLUSION}

The findings of the study show how altruism has an impact on employee performance with specific reference to L\&T. The analysis results show that the employees have exhibited high levels of OCB in the organization by means of antecedent like altruism. The analysis also shows that the impact on employee satisfaction is very positive. When one employee exhibits such zeal, it is definite to encourage others also to do so, resulting in greater degree of OCB which means greater benefit to the organization.

\section{REFERENCES}

1. Aube.C., Rousseau.V., \& Morin.E.M. (2007). Perceived organizational support and organizational commitment. The moderating effect of locus of control and work autonomy. Journal of Managerial Psychology ,22 (5),479495.

2. Joireman, J., Daniels, D., Falvy, J., \& Kamdar, D. (2006). Organizational Citizenship Behavior as Function Of Empathy Consideration of Future Consequences, And Employee Time Horizon: An Initial Exploration Using An In-Basket Simulation of OCBs. Journal of Applied Social Psychology, Vol. 36, No. 9, pp.2266-2292. 